\title{
Prevalence and determinants of the use of pacifiers and feedingbottle: a study in Southwest Bahia
}

Vanessa Moraes Bezerra 1

iD https://orcid.org/0000-0001-5333-2875

Elma Izze da Silva Magalhães 2

https://orcid.org/0000-0001-9909-9861

Itana Neves Pereira 3

https://orcid.org/0000-0002-7593-4778

Andressa Tavares Gomes 4

https://orcid.org/0000-0002-5366-2804

Michele Pereira Netto 5

https://orcid.org/0000-0003-0017-6578

Daniela da Silva Rocha 6

https://orcid.org/0000-0001-6969-6841

1,3,4,6 Instituto Multidisciplinar em Saúde. Universidade Federal da Bahia. Rua Rio de Contas, 58. Candeias. Vitória da Conquista, BA, Brasil. CEP: 45.029-094. E-mail: vanessaenut@yahoo.com.br

2 Programa de Pós-Graduação em Epidemiologia. Universidade Federal de Pelotas. Pelotas, RS, Brasil

5 Faculdade de Nutrição. Universidade Federal de Juiz de Fora. Juiz de Fora, MG, Brasil.

\section{Abstract}

Objectives: to assess the use of pacifier and feedingbottle and their determinants in children from a municipality of Southwest Bahia.

Methods: a cross-sectional study was performed with 354 children younger than 12 months old. The event was categorized in: exclusive use of pacifier, exclusive use of feeding bottle, use of pacifier and feeding bottle, and not use any of them. Multinomial analysis with logistic regression was applied, and those who did not use any artificial nipples were thereference variable.

Results: it was observed that $11.9 \%$ of the children exclusively used pacifiers, $21.2 \%$ only use bottles and $32.8 \%$ used both of them. The following factors were associated with the exclusive use of pacifiers: low maternal schooling level (eight or less years of education), lack of previous experience with breastfeeding, difficulty in postpartum breastfeeding, and lack of incentive to breastfeeding in puericulture. The exclusive use of feeding bottle was associated with unmarried mothers, aged 35 years old or older, and with less years of education (eight or less years). Women who worked outside home and had difficulty in breastfeeding had greater chance of giving both artificial nipples to the children.

Conclusions: the findingspresent different featuresrelated to the exclusive or combined use of pacifiers and feeding bottles, being important to direct health professionals conducts towards mothers'orientation.

Key words Pacifiers, Feeding bottles, Epidemiological studies

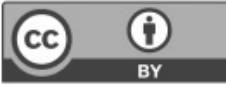




\section{Introduction}

The World Health Organization (WHO) and the United Nations Children's Fund (UNICEF) recommendnot offering pacifiers or feeding bottleto breastfed children as an important step towards breastfeeding success. ${ }^{1}$ This instruction takes into account the possibility of "nipplesconfusion" by the infant, resulting in an oral configuration and sucking pattern inappropriate for breastfeeding after exposure to the artificial nipples, ${ }^{2}$ which contributes to early weaning. ${ }^{3}$

Studies have shown that the use of pacifiers and/or feeding bottle favors early breastfeeding discontinuance, interferes with the development of orofacial structures, alterschild chewing and swallowing functions, 4 is associated with higher risk of cariesoccurrence 5 and teeth malocclusion, 6 besides it has been considered an important source of contamination by microorganisms harmful to health. ${ }^{7}$

In Brazil, some regulations were established in order to supervise the trade of infant products, including pacifiers and baby bottles. The Brazilian Standard for Commercialization of Foods for Infants and Young Children, Pacifiers, and Baby Bottles (NBCAL - Norma Brasileira de Comercialização de Alimentos para Lactentes e Crianças de $1^{a}$ Infância, Bicos, Chupetas e Mamadeiras), later changed into Law No. $11265 / 2006,8$ aims to ensure the appropriate use of these products in a way that does not interfere with breastfeeding practice.Despite that, artificial nipples are still widely used in Brazil and in several countries worldwide, being a cultural practice widely disseminated in our environment. 4

In literature, researches evaluating the use of artificial nipples have shown association with several factors, such as low maternal schooling, maternal age under 20 years old, nipple trauma, cohabitation with maternal grandmother, maternal work outside home, primiparity, cesarean section, low birth weight, lack of breastfeeding in the first hour of life, among others. ${ }^{9-13}$ Most of these studieshave only assessed the determinants of exclusive use of pacifiers 9,10 or exclusive use feeding bottle, 11,12 thus, studies investigating the combined use of both artificialnipples and their associated factors are still scarce. ${ }^{13}$

Hence, this work aimed to assess the prevalence of exclusive and combined use of pacifiers and feeding bottles and their determinants in children younger than one year old living in a municipality in Southwest Bahia, Brazil.

\section{Methods}

It is a cross-sectional study with data obtained from a larger research project, entitled "Breastfeeding frequency and factors associated with early weaning in the city of Vitória da Conquista, Bahia".

For sample calculation, we considered the total number of children younger than one year old,born between June 2009 and May $2010(\mathrm{n}=5222)$, the prevalence of pacifier use $(42.6 \%),{ }^{14}$ confidence interval of $95 \%$, originating a minimum sample of 351 children. Inclusion criteria were children younger than 12 months old that was attended at the city health units. Children who had health problems that interfered with feeding as well as those who were not accompanied by the mother or legal guardian were excluded.

The sample was selected from January 2011 to April 2012 and included children younger than one year old who attended the Child Growth and Development (GD) appointments in all health units of the urban area of the municipality, comprising 15 family health units, three polyclinics for primary care, and three health centers.

The interviews were conducted by Nutrition students from Federal University of Bahia (UFBA), Anísio Teixeira campus, all of them had been properly trained by the project supervisors. Semi-structured interviews were carried out with children's mothers.

The study dependent variable was the use of pacifiers and/or feeding bottles. Two questions were asked: "Does the child use pacifiers?" "Does the child use feeding bottles?" The outcome was divided into four categories: exclusive use of pacifier, exclusive use of feeding bottle, use of pacifier and feeding bottle, and non-use of pacifiers and feeding bottle.

The independent variables were established through a conceptual model for the determinants of the use of pacifiers and/or feeding bottles, adapted from a model proposed by Buccini et al. 13 being organized into four blocks (Figure 1).

For the first group, the following maternal sociodemographic variables were considered: age ( $<20$ years old, 20 to 34 years old, and $\geq 35$ years old), primiparous (Yes / No), marital status (with partner / without partner), family income of 1 minimum wage, $>1$ minimum wage, schooling level ( $\leq 8$ years of education $/>8$ years of education), and work outside the home (Yes / No); the variables concerned to child's birth conditions, in its turn, comprised the second block, and were: type of delivery (vaginal / cesarean-section), child gender (male / female), and birth weight $(\geq 2500 \mathrm{~g} /$ 


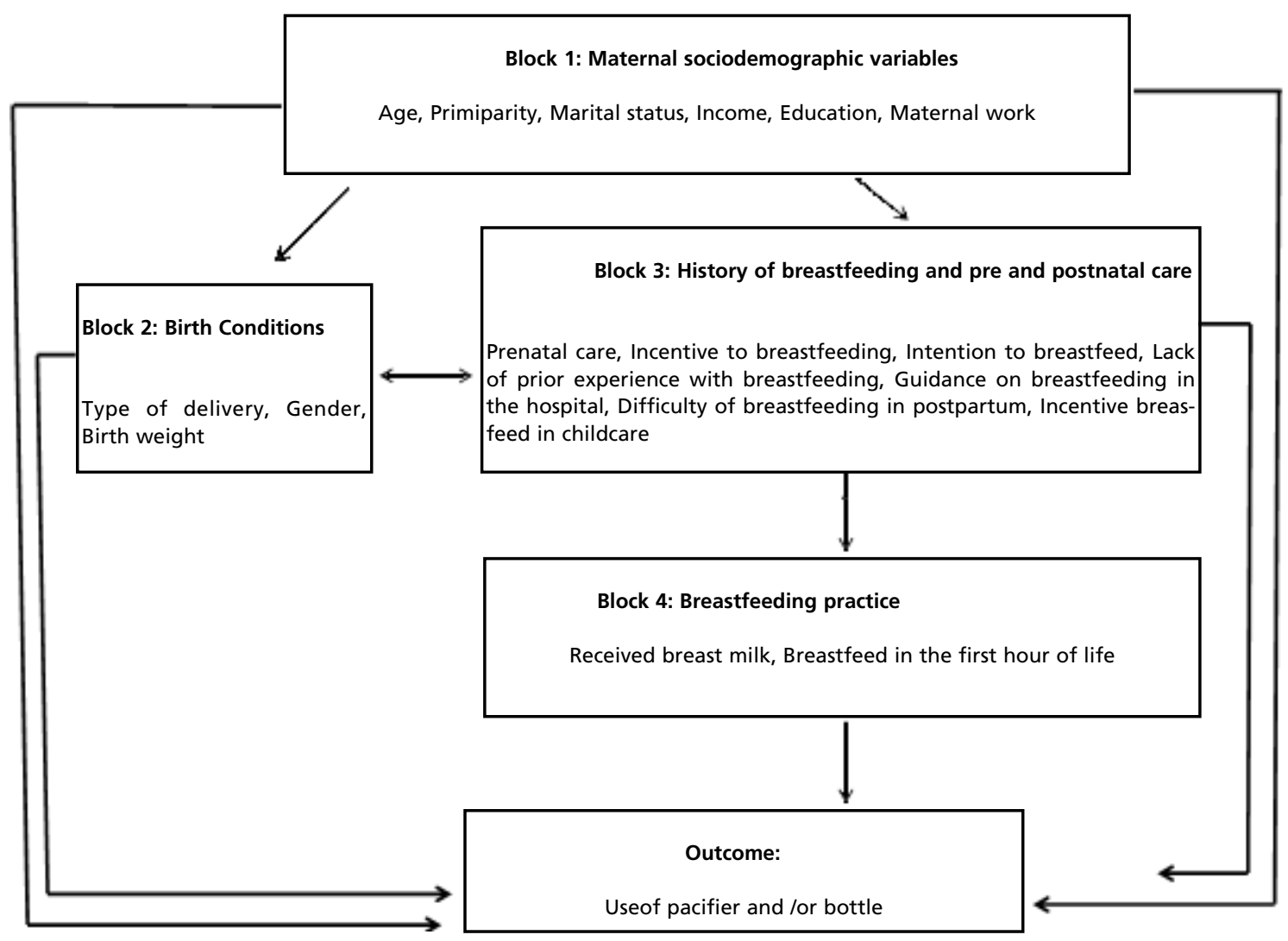

Adapted from Buccini et al.13

$<2500 \mathrm{~g}$ ); Prenatal and postnatal care: prenatal care, breastfeeding in prenatal care, previous desire to breastfeed, previous experience with breastfeeding, breastfeeding orientation and encouragement in the hospital, difficulty in postpartum breastfeeding, and breastfeeding incentive. The fourth group consisted of two variables: breastfeeding (independent of the type) and breastfeeding in the first hour of life, which were also analyzed in a dichotomous way (Yes / No).

Initially, a descriptive analysis of the population and an estimate of prevalence of pacifier and/or feeding bottle use among children with 95\% Confidence Intervals (CI95\%) were performed. Differences between groups were assessed using the Pearson chi-square test or Fisher's exact test. For multivariate analysis, the variables that presented statistical significance of $p<0.20$ were selected. Multinomial logistic regression was used to deter- mine the factors associated with exclusive use of pacifiers, exclusive use of feeding bottle, and combined use of pacifiers and feeding bottle, considering those who did not use any of these artificial nipples as reference. The odds ratio and CI95\% were calculated taking into account a dependent variable with more than two nominal categories.

The hierarchical entry of the variables into blocks 15 was adopted, according to the following order: maternal sociodemographic variables; variables on child's birth conditions; variables of breastfeeding history and pre- and postnatal care; and variables on the practice of breastfeeding. Adjustments for variables of the same block and of hierarchically superior blocks were done, remaining in the model those that presented $p \leq 0.05$. The model comparison was performed using the Akaike criterion (AIC) and the suitability of the models was verified by the Hosmer-Lemeshow test for the multinomial model. 
All analyzes were performed using Stata software version 12.0 (StataCorp, College Station, Texas, USA).

The project was approved by the Ethics Committee of the Sponsor Institute of Higher Education (CEP / IMES) No 2.072 in accordance with the guidelines of National Health Council Resolution No. 196/96. Participants were informed about the purpose of the work, procedures, and data confidentiality, and expressed their agreement in participating on the research by signing the informed consent form.

\section{Results}

From the 381 children younger than 12 months old attending health units, 354 have participated in the study. The percentage of $7.0 \%$ of non-participation is explained by absence of the child mother or legal guardian at the time of the survey or by refusal to take part.

Most of them were female, were born by vaginal delivery, and weighed $2.500 \mathrm{~g}$ or more. It was also observed that most of the mothers interviewed were between 20 and 34 years old, were primiparous, andworked outside home. It was also found that more than half of the children (64.7\%) had breastfed in the first hour of life and almost all population (96.3\%) was receiving breast milk (Table 1).

Regarding prenatal and postnatal care, more than $90 \%$ of the mothers had prenatal follow-up, incentive to breastfeed during pregnancy and had prior desire to breastfeed. The orientation and incentive to breastfeeding in the hospital inpuericulture was reported by $88.4 \%$ and $77.2 \%$ of the mothers respec- tively (Table 1).

In regards to the investigated event, $11.9 \%$ $(\mathrm{CI} 95 \%=8.48-15.25)$ of the children only used pacifiers, $21.2 \%(\mathrm{CI} 95 \%=16.9-25.5)$ only used feeding bottle, $32.8 \%(\mathrm{CI} 95 \%=27.7-37.7)$ used both of them, and $34.1 \%(\mathrm{CI} 95 \%=29.2-39.1) \mathrm{did}$ not use pacifiers or baby bottles (Figure 2).

In bivariate analysis, a greater proportion of exclusive pacifier use and combined use of pacifier and feeding bottle were verified among the children of married mothers, with nine or more years of education, who worked outside home, who had difficulty in breastfeeding post-childbirth. All population who exclusively used pacifiers reported that they had already offered breast milk. For the exclusive use of feeding bottle, superior proportions were observed for the same variables mentioned above, except for difficulty in postpartum breastfeeding, in which the highest proportion of feeding bottle use was among the group that reported having no difficulty (Table 2).

In multinomial logistic regression analysis, it was observed that lower maternal schooling (eight or less years) had a negative association with pacifier use alone ( $\mathrm{OR}=0.47 ; p=0.045)$ and with exclusive use of feeding bottle $(\mathrm{OR}=0.53 ; \mathrm{p}=0.044)$. However, the lack of previous experience with breastfeeding $(\mathrm{OR}=2.56 ; p=0.027)$, difficulty in postpartum breastfeeding $(\mathrm{OR}=2.51, p=0.017)$, and non-encouragement of breastfeeding in puericulture $(\mathrm{OR}=2.25, p=0.048)$ exhibited a positive association with the exclusive use of pacifier. Being a child of unmarried $(\mathrm{OR}=2.72, p=0.034)$ and older mothers $(\mathrm{OR}=3.53, p=0.038)$ had a significant positive association with exclusive use of feeding

Table 1

Distribution of the characteristics of children under 12 months in a municipality in the Southwest of Bahia - BA, $2011 / 2012(n=354)$.

\begin{tabular}{|c|c|c|c|}
\hline Variables & $\mathbf{N}$ & $\%$ & $\mathrm{Cl} 95 \%$ \\
\hline \multicolumn{4}{|c|}{ Sociodemographic and maternal variables } \\
\hline \multicolumn{4}{|l|}{ Maternal age (years) } \\
\hline$<20$ & 62 & 17.5 & $13.53-21.49$ \\
\hline $20-34$ & 255 & 72.0 & $67.33-76.73$ \\
\hline$\geq 35$ & 37 & 10.5 & $7.24-13.65$ \\
\hline \multicolumn{4}{|l|}{ Primiparity } \\
\hline Yes & 173 & 51.1 & $45.89-56.36$ \\
\hline No & 181 & 48.9 & $43.63-54.10$ \\
\hline \multicolumn{4}{|l|}{ Marital status } \\
\hline No husband/partner & 309 & 87.3 & $83.80-90.77$ \\
\hline With husband/partner & 45 & 12.7 & $9.22-16.19$ \\
\hline \multicolumn{4}{|c|}{ Family income (minimum wage) } \\
\hline$\leq 1$ & 175 & 49.7 & $44.47-54.96$ \\
\hline$>1$ & 177 & 50.3 & $45.04-55.53$ \\
\hline
\end{tabular}


Distribution of the characteristics of children under 12 months in a municipality in the Southwest of Bahia - BA, $2011 / 2012(n=354)$

\begin{tabular}{|c|c|c|c|}
\hline Variables & $\mathbf{N}$ & $\%$ & $\mathrm{Cl} 195 \%$ \\
\hline \multicolumn{4}{|c|}{ Maternal education (years of study) } \\
\hline$\geq 9$ & 186 & 52.5 & $47.32-57.77$ \\
\hline$\leq 8$ & 168 & 47.5 & $42.23-52.68$ \\
\hline \multicolumn{4}{|c|}{ Maternal working outside home } \\
\hline Yes & 274 & 77.4 & $73.02-81.77$ \\
\hline No & 80 & 22.6 & $18.22-26.97$ \\
\hline \multicolumn{4}{|c|}{ Birth conditions } \\
\hline \multicolumn{4}{|c|}{ Type of delivery } \\
\hline Vaginal & 232 & 65.9 & $60.93-70.88$ \\
\hline Cesarean & 120 & 34.1 & $29.11-39.06$ \\
\hline \multicolumn{4}{|l|}{ Gender } \\
\hline Male & 173 & 48.9 & $45.89-56.36$ \\
\hline Female & 181 & 51.1 & $43.63-54.10$ \\
\hline \multicolumn{4}{|c|}{ Birthweight (g) } \\
\hline$\geq 2500$ & 323 & 92.8 & $90.08-95.54$ \\
\hline$<2500$ & 25 & 7.2 & $4.45-9.91$ \\
\hline \multicolumn{4}{|c|}{ History of breastfeeding and pre and postnatal care } \\
\hline \multicolumn{4}{|l|}{ Prenatal care } \\
\hline Yes & 350 & 98.9 & $97.76-99.97$ \\
\hline No & 4 & 1.1 & $02.35-2.23$ \\
\hline \multicolumn{4}{|c|}{ Incentive to breastfeeding during prenatal care } \\
\hline Yes & 316 & 90.0 & $86.87-93.17$ \\
\hline No & 35 & 10.0 & $06.82-13.12$ \\
\hline \multicolumn{4}{|c|}{ Intention to breastfeed } \\
\hline Yes & 326 & 92.1 & $89.26-94.91$ \\
\hline No & 28 & 7.9 & $5.08-10.73$ \\
\hline \multicolumn{4}{|c|}{ Lack of prior experience with breastfeeding } \\
\hline Yes & 165 & 46.7 & $41.51-51.97$ \\
\hline No & 188 & 53.3 & $48.02-58.48$ \\
\hline \multicolumn{4}{|c|}{ Guidance on Breastfeeding in the hospital } \\
\hline Yes & 311 & 88.4 & $84.98-91.71$ \\
\hline No & 41 & 11.6 & $8.28-15.01$ \\
\hline \multicolumn{4}{|c|}{ Difficulty of breastfeeding in postpartum } \\
\hline Yes & 178 & 50.3 & $44.48-54.95$ \\
\hline No & 176 & 49.7 & $45.04-55.51$ \\
\hline \multicolumn{4}{|c|}{ Incentive breastfeed in childcare } \\
\hline Yes & 271 & 77.2 & $72.79-81.61$ \\
\hline No & 80 & 22.8 & $18.38-27.20$ \\
\hline \multicolumn{4}{|c|}{ Breastfeeding practice } \\
\hline \multicolumn{4}{|c|}{ Receives/ received breast milk } \\
\hline Yes & 341 & 96.3 & $94.35-98.29$ \\
\hline No & 13 & 3.7 & $1.70-5.64$ \\
\hline \multicolumn{4}{|c|}{ Breastfeed in the first hour of life } \\
\hline Yes & 229 & 64.7 & $59.68-69.69$ \\
\hline No & 125 & 35.3 & $30.30-40.31$ \\
\hline
\end{tabular}


bottle. Women who worked outsidehome $(\mathrm{OR}=$ $1.99, p=0.043)$ and had difficulty in breastfeeding
$(\mathrm{OR}=1.80, p=0.030)$ were more likely to use both artificial nipples (Table 3).

\section{Figure 2}

Prevalence of the use of pacifiers, bottles, both of them and no artificial nozzle in children under 12 months from a municipality in the Southwest of Bahia - BA, 2011/2012.

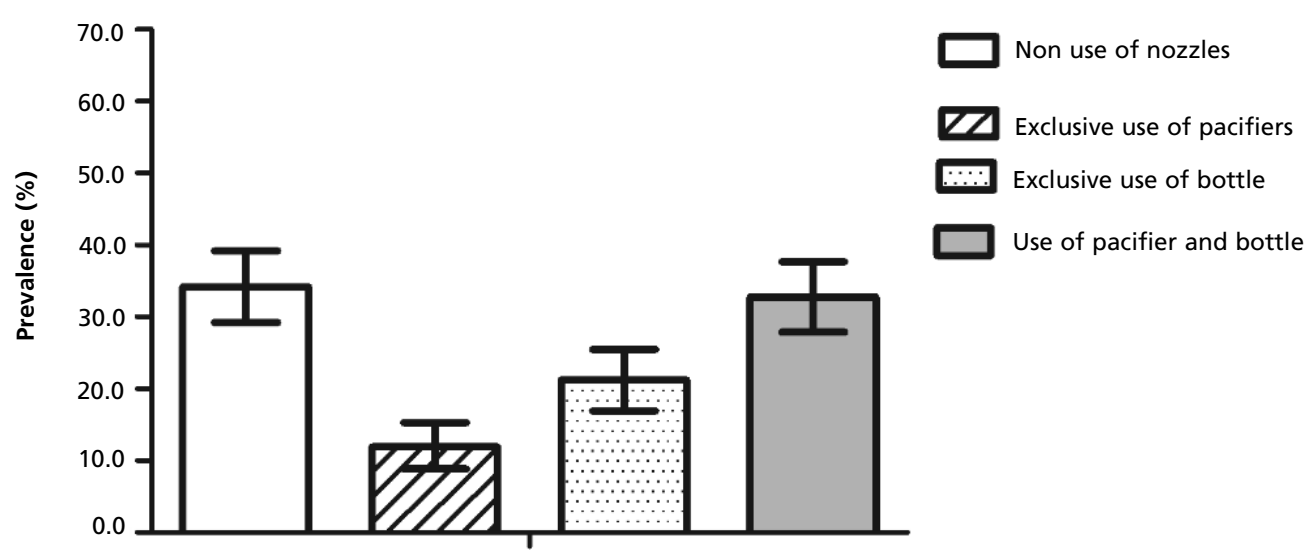

Table 2

Distribution of the use of artificial nozzles in relation to sociodemographic and maternal variables, birth conditions, prenatal and postnatal care in breastfeeding in children under 12 months of age in a city in the Southwest of Bahia $2011 / 2012$.

\begin{tabular}{|c|c|c|c|c|c|c|c|c|c|}
\hline \multirow[t]{2}{*}{ Variables } & \multicolumn{2}{|c|}{$\begin{array}{c}\text { Non use of } \\
\text { nozzles }(n=121)\end{array}$} & \multicolumn{2}{|c|}{$\begin{array}{l}\text { Use of pacifier } \\
\qquad(n=42)\end{array}$} & \multicolumn{2}{|c|}{$\begin{array}{l}\text { Use bottle } \\
\qquad(n=75)\end{array}$} & \multicolumn{2}{|c|}{$\begin{array}{c}\text { Use of pacifier and } \\
\text { bottle }(n=116)\end{array}$} & \multirow[t]{2}{*}{$p$} \\
\hline & $\mathrm{n}$ & $\%$ & $\mathrm{n}$ & $\%$ & $\mathrm{n}$ & $\%$ & $\mathrm{n}$ & $\%$ & \\
\hline \multicolumn{10}{|l|}{ Block 1: Sociodemographic } \\
\hline \multicolumn{10}{|l|}{ Maternal age (years) } \\
\hline$<20$ & 26 & 21.5 & 7 & 16.7 & 7 & 9.3 & 22 & 19.0 & 0.189 \\
\hline $20-34$ & 84 & 69.4 & 31 & 73.8 & 55 & 73.3 & 85 & 73.3 & \\
\hline$\geq 35$ or more & 11 & 9.1 & 4 & 9.5 & 13 & 17.3 & 9 & 7.8 & \\
\hline \multicolumn{10}{|l|}{ Primiparity } \\
\hline Yes & 54 & 44.6 & 25 & 59.5 & 37 & 49.3 & 57 & 49.1 & 0.425 \\
\hline No & 67 & 55.4 & 17 & 40.5 & 38 & 50.7 & 59 & 50.9 & \\
\hline \multicolumn{10}{|l|}{ Marital status } \\
\hline No husband/partner & 112 & 92.6 & 39 & 92.9 & 61 & 81.3 & 97 & 83.6 & 0.046 \\
\hline With husband/partner & 9 & 7.4 & 3 & 7.1 & 14 & 18.7 & 19 & 16.4 & \\
\hline \multicolumn{10}{|c|}{ Family income (minimum wage) } \\
\hline$\leq 1$ & 65 & 54.2 & 17 & 40.5 & 34 & 45.3 & 59 & 51.3 & 0.380 \\
\hline$>1$ & 55 & 45.8 & 25 & 59.5 & 41 & 54.7 & 56 & 48.7 & \\
\hline \multicolumn{10}{|c|}{ Maternal education (years of study) } \\
\hline$\geq 9$ & 52 & 43.0 & 26 & 61.9 & 47 & 62.7 & 61 & 52.6 & 0.029 \\
\hline$\leq 8$ & 69 & 57.0 & 16 & 38.1 & 28 & 37.3 & 55 & 47.4 & \\
\hline
\end{tabular}


Distribution of the use of artificial nozzles in relation to sociodemographic and maternal variables, birth conditions, prenatal and postnatal care in breastfeeding in children under 12 months of age in a city in the Southwest of Bahia $-2011 / 2012$.

\begin{tabular}{|c|c|c|c|c|c|c|c|c|c|}
\hline \multirow[t]{2}{*}{ Variables } & \multicolumn{2}{|c|}{$\begin{array}{c}\text { Non use of } \\
\text { nozzles }(n=121)\end{array}$} & \multicolumn{2}{|c|}{$\begin{array}{l}\text { Use of pacifier } \\
\qquad(n=42)\end{array}$} & \multicolumn{2}{|c|}{$\begin{array}{l}\text { Use bottle } \\
(n=75)\end{array}$} & \multicolumn{2}{|c|}{$\begin{array}{l}\text { Use of pacifier and } \\
\text { bottle }(n=116)\end{array}$} & \multirow[t]{2}{*}{$p$} \\
\hline & $\mathrm{n}$ & $\%$ & $\mathrm{n}$ & $\%$ & $\mathrm{n}$ & $\%$ & $\mathrm{n}$ & $\%$ & \\
\hline \multicolumn{10}{|c|}{ Maternal working outside home } \\
\hline Yes & 103 & 85.1 & 35 & 83.3 & 52 & 69.3 & 84 & 72.4 & 0.024 \\
\hline No & 18 & 14.9 & 7 & 16.7 & 23 & 30.7 & 32 & 27.6 & \\
\hline \multicolumn{10}{|c|}{ Block 2: Birth conditions } \\
\hline \multicolumn{10}{|c|}{ Type of delivery } \\
\hline Vaginal & 81 & 67.5 & 25 & 59.5 & 44 & 59.5 & 82 & 70.7 & 0.328 \\
\hline Cesarean & 39 & 32.5 & 17 & 40.5 & 30 & 40.5 & 34 & 29.3 & \\
\hline \multicolumn{10}{|l|}{ Gender } \\
\hline Male & 60 & 50.4 & 20 & 47.6 & 34 & 45.3 & 59 & 50.9 & 0.894 \\
\hline Female & 61 & 50.4 & 22 & 52.4 & 41 & 54.7 & 57 & 59.1 & \\
\hline \multicolumn{10}{|c|}{ Birth weight $(\mathrm{g})$} \\
\hline$\geq 2500$ & 110 & 93.2 & 42 & 100.0 & 67 & 90.5 & 104 & 91.2 & 0.232 \\
\hline$<2500$ & 8 & 6.8 & 0 & 0 & 7 & 9.5 & 10 & 8.7 & \\
\hline \multicolumn{10}{|c|}{$\begin{array}{l}\text { Block 3: History of breastfeeding and pre and } \\
\text { postnatal care }\end{array}$} \\
\hline \multicolumn{10}{|l|}{ Prenatal care } \\
\hline Yes & 121 & 100.0 & 42 & 100 & 74 & 98.7 & 113 & 97.4 & 0.252 \\
\hline No & 0 & 0.0 & 0 & 0.0 & 1 & 1.3 & 3 & 2.6 & \\
\hline \multicolumn{10}{|c|}{ Incentive to breastfeeding during prenatal care } \\
\hline Yes & 108 & 89.3 & 38 & 90.5 & 65 & 87.8 & 105 & 92.1 & 0.793 \\
\hline No & 13 & 10.7 & 4 & 9.5 & 9 & 12.1 & 9 & 7.9 & \\
\hline \multicolumn{10}{|c|}{ Intention to breastfeed } \\
\hline Yes & 112 & 92.6 & 38 & 90.5 & 70 & 93.3 & 106 & 91.4 & 0.935 \\
\hline No & 9 & 7.4 & 4 & 9.5 & 5 & 6.7 & 10 & 8.6 & \\
\hline \multicolumn{10}{|c|}{ Lack of prior experience with breastfeeding } \\
\hline Yes & 65 & 53.7 & 15 & 35.7 & 36 & 48.0 & 49 & 42.6 & 0.154 \\
\hline No & 56 & 46.3 & 27 & 64.3 & 39 & 52.0 & 66 & 57.4 & \\
\hline \multicolumn{10}{|c|}{ Guidance on Breastfeeding in the hospital } \\
\hline Yes & 107 & 88.4 & 37 & 88.1 & 63 & 84.0 & 104 & 91.2 & 0.513 \\
\hline No & 14 & 11.6 & 5 & 11.9 & 12 & 16.0 & 10 & 8.8 & \\
\hline \multicolumn{10}{|c|}{ Difficulty of breastfeeding in postpartum } \\
\hline Yes & 53 & 43.8 & 28 & 66.7 & 31 & 41.3 & 66 & 56.9 & 0.012 \\
\hline No & 68 & 56.2 & 14 & 33.3 & 44 & 58.7 & 50 & 43.1 & \\
\hline \multicolumn{10}{|c|}{ Incentive breastfeed in childcare } \\
\hline Yes & 96 & 80.0 & 27 & 64.3 & 59 & 78.7 & 89 & 78.1 & 0.199 \\
\hline No & 24 & 20.0 & 15 & 35.7 & 16 & 21.3 & 25 & 21.9 & \\
\hline \multicolumn{10}{|c|}{ Block 4: Breastfeeding practice } \\
\hline \multicolumn{10}{|c|}{ Receives/ received breast milk } \\
\hline Yes & 121 & 100.0 & 42 & 100.0 & 68 & 90.7 & 110 & 94.8 & 0.003 \\
\hline No & 0 & 0.0 & 0 & 0.0 & 7 & 9.3 & 6 & 5.2 & \\
\hline \multicolumn{10}{|c|}{ Breastfeed in the first hour of life } \\
\hline Yes & 84 & 69.4 & 23 & 54.8 & 45 & 60.0 & 77 & 66.4 & 0.276 \\
\hline No & 37 & 30.6 & 19 & 45.2 & 30 & 40.0 & 39 & 33.6 & \\
\hline
\end{tabular}


Adjusted analysis of factors associated with exclusive use of pacifiers, exclusive use of bottles and use of pacifiers and bottles in children with less than 12 months in a municipality of the Southwest of Bahia BA, 2011/2012.

\begin{tabular}{|c|c|c|c|c|c|c|}
\hline \multirow[t]{2}{*}{ Variables } & \multicolumn{2}{|c|}{ Use of pacifier } & \multicolumn{2}{|c|}{ Use of bottle } & \multicolumn{2}{|c|}{$\begin{array}{c}\text { Use of pacifier } \\
\text { and bottle }\end{array}$} \\
\hline & OR & $\mathrm{Cl} 95 \%$ & OR & $\mathrm{Cl} 95 \%$ & OR & $\mathrm{Cl} 95 \%$ \\
\hline \multicolumn{7}{|l|}{ Sociodemographic ${ }^{\dagger}$} \\
\hline \multicolumn{7}{|l|}{ Maternal age (years) } \\
\hline$<20$ & 1.00 & & 1.00 & & 1.00 & \\
\hline $20-34$ & 1.18 & $0.46-3.07$ & 2.02 & $0.80-5.15$ & 1.05 & $0.54-2.05$ \\
\hline$\geq 35$ & 1.20 & $0.28-5.05$ & 3.53 & $1.07-11.65$ & 0.81 & $0.28-2.39$ \\
\hline \multicolumn{7}{|l|}{ Marital status } \\
\hline No husband/partner & 1.00 & & 1,00 & & 1.00 & \\
\hline With husband/partner & 0.96 & $0.24-3.77$ & 2.72 & $1.08-6.86$ & 2.32 & $0.99-5.44$ \\
\hline \multicolumn{7}{|c|}{ Maternal education (years of study) } \\
\hline$\geq 9$ & 1.00 & & 1.00 & & 1.00 & \\
\hline$\leq 8$ & 0.47 & $0.23-0.98$ & 0.53 & $0.29-0.98$ & 0.76 & $0.45-1.29$ \\
\hline \multicolumn{7}{|c|}{ Maternal working outside home } \\
\hline Yes & 1.00 & & & & 1.00 & \\
\hline No & 0.97 & $0.37-2.58$ & 1.88 & $0.90-3.90$ & 1.99 & $1.02-3.87$ \\
\hline \multicolumn{7}{|c|}{ History of breastfeeding and pre and } \\
\hline \multicolumn{7}{|l|}{ postnatal care $\ddagger$} \\
\hline \multicolumn{7}{|c|}{ Lack of prior experience with breastfeeding } \\
\hline Yes & 1.00 & & 1.00 & & 1.00 & \\
\hline No & 2.56 & $1.11-5.90$ & 1.46 & $0.75-2.86$ & 1.59 & $0.87-2.91$ \\
\hline \multicolumn{7}{|c|}{ Difficulty of breastfeeding in postpartum } \\
\hline Yes & 1.00 & & 1.00 & & 1.00 & \\
\hline No & 2.51 & $1.18-5.33$ & 0.98 & $0.54-1.80$ & 1.80 & $1.06-3.05$ \\
\hline \multicolumn{7}{|c|}{ Incentive breastfeed in childcare } \\
\hline Yes & 1.00 & & 1.00 & & 1.00 & \\
\hline No & 2.25 & $1.01-5.02$ & 1.15 & $0.55-2.40$ & 1.09 & $0.58-2.08$ \\
\hline
\end{tabular}

$\mathrm{OR}=$ adjusted odds ratio for the variables contained in the model; $\mathrm{Cl} 95 \%=$ Confidence interval;

The reference was not using pacifier and bottle (nonuse anything)

$(+)$ Adjusted among sociodemographic variables:

( )Adjusted between sociodemographic variables and pre and post natal care.

\section{Discusion}

This research estimated the prevalence and investigated the determinants of pacifier and/or feedingbottle use in children younger than 12 months old in a municipality of Southwest Bahia. The prevalence of the use of artificial nipples in the investigated population was high, and only $34.1 \%$ did not use pacifiers or feeding bottles, and their usage was associated with sociodemographic factors, experience and difficulties in the breastfeeding process and encouragement.

Related to the combined use of pacifiers and feeding bottle, the verified prevalence was similar to the data from II National Survey on Breastfeeding Prevalence (33.5\%). ${ }^{13}$ Regarding the exclusive use of these artificial nipples, the prevalence of use of pacifier was higher than the one reported in the National Survey $(9.1 \%)$, while the prevalence of use of feeding bottle was lower than that reported in the same survey $(24.8 \%){ }^{13}$ In Bahia State, as well as in Northeast region as a whole, higher prevalence of exclusive use of pacifiers (48.7\% and $43.6 \%)$ and exclusive use of feeding bottle $(63.6 \%$ and $60 \%)$ are recorded when compared to the frequencies observed in this study. ${ }^{14}$

Lower maternal schooling showed a negative association with exclusive use of pacifiers and exclusive use of feeding bottle, even after adjust- 
ment by other variables. These findings were also seen among children of working women in the interior of São Paulo. 16 However, in literature, there have been reports of divergent results. In a study conducted by Tomasi et al., ${ }^{9}$ a superior frequency of pacifier use was verified among children of mothers with low schooling level, and in the study by Shamim et al.,12 maternal illiteracy was one of the determinants for feeding bottle use.

Regarding this research's findings, it is suggested that this lower chance of exclusive use of pacifiers and feeding bottle may be related, in part, to the greater frequency of receiving information about breastfeeding (which includes the recommendation for not offering artificial nipples) in health services by women with low schooling level. The research carried out by Cruz et al.17 may reinforce this hypothesis, as they have detected a higher prevalence of having received all the guidelines on breastfeeding among women with lower schooling level who attended basic health units in their coverage area during prenatal.

Children of women who have reported difficulty in breastfeeding in postpartum period presented greater chances of exclusive use of pacifiers as well as the combined use of pacifiers and bottle. In regards to the exclusive use of pacifiers, some authors have pointed to this event as a marker of the challenges in breastfeeding. 18,19 The difficulties faced by nursing mothers in the breastfeeding process may favor the use of pacifiers, considering that many mothers attribute pacifiers to the so-called "infant tranquilizer" function. 20 Thus, the need to calm the crying and the natural restlessness of newborns, which is intensified in the presence of difficulty in breastfeeding, can lead mothers to offer pacifiers to their children, and once established, thishabit does not change over time. ${ }^{10}$ Besides, pacifiers can be used as a mechanism to decrease and space breastfeeding in women with breastfeeding difficulties, thus relieving discomfort during the process. ${ }^{21}$

Related to the combined use of pacifiers and feeding bottle, it is possible that, given a difficult breastfeeding scenario, the use of pacifiers contributes to a reduction in the number of breastfeeds and a consequent lower stimulation of the breasts, resulting in reduced milk production, ${ }^{22}$ which leads the mother to also offer the feeding bottle with another type of milk to satisfy the child. Besides, confronting the obstacles that hamper breastfeeding, feeding bottle is an easier alternative to feed the child, since in this utensil milk is ingested more quickly and without causing discomfort to the mother. 23

The replacement of natural breastfeeding by the feeding bottle can cause damage to the sensorimotororal system development, due to the lack of correct stimulation of orofacial structures, favoring the installation of oral sucking habits, such as those triggered by the pacifier. ${ }^{24}$ Thus, it is presumed that the obstacle in breastfeeding facilitate the use of pacifier or feeding bottle, and the use of one of these nipples may also ease the use of the other one.

The lack of experience in and the non-incentive forbreastfeeding in puericulture also showed a positive association with theuse of pacifiers alone. For the lack of prior breastfeeding experience, this association may be related to the fact that mothers who have never breastfed tend to interpret the newborn's crying and natural agitation as a sign of hunger or dissatisfaction even after the child has been breastfed. According to Sertório and Silva, 25 inexperienced mothers may qualify breastfeeding as insufficient, in terms of satiating the infant suckling need so that they start looking for alternatives to ensure the baby's satisfaction and "complement" breastfeeding with the pacifier, obtaining the expected result, when effectively the child has already been satiated.

Regardingthe association of the exclusive use of pacifiers with the non-incentive to breastfeeding in childcare, it is well established in literature that the use of artificial nipples, such as pacifier, contributes to early interruption of breastfeeding. $3,15,18,20,21$ Evidently, the encouragement of breastfeeding in puericulture by health professionals includes, among other recommendations, discouraging the use of artificial nipples. 26 Indeed, when properly oriented, parents feel safer to comfort the child in a crying crisis without using artificial nipples. 18

It was also observed that the children of women aged 35 years old or older living with no partner had a higher chance of exclusive use of feeding bottle. Literature has shown controversial results on maternal age. In the study by Shamim et al.12 mothers aged over 30 years showed a higher preference for feeding bottle, while França et al. ${ }^{11}$ have observed greater chance of using bottle among the children of teenage mothers. It is assumed that the association between maternal age and exclusive use of feeding bottle is related to the fact that older women may have a busy daily routine, which includes their insertion in the marketas well as to perform home care activities. In this regard, the mothers would opt for the use of feeding bottle, considering that in addition to allowing the food to be eaten more quickly, it provides more freedom to 
perform other activities, since another person can offer it to the baby. 23

Regarding the association between marital status and exclusive use of feeding bottle, literature have brought the fact that the mother in a stable union can have a positive impact on breastfeeding, considering that when a father or partner offers the support necessary for breastfeeding, it can exert a positive influence on the duration of breastfeeding. 27,28 Therefore, mothers who do not have a partner would choose to offer other milk or formulations to the detriment of breastfeeding, due to the lack of support in the family environment, particularly from the parent or partner.

Maternal work outside the home was related to combined use of pacifiers and feeding bottle, which corroborates Buccini et al.13 findings. According to Rea et al.,29 the conciliation of the roles of mother and worker is increasingly common, making necessary that more labor benefits are created so that mothers continue breastfeeding and do not introduce artificial nipples to their children.

This study has limitations due to the crosssectional design, thus, for some detected associations it is not possible to establish an accurate temporal relationship between exposure and outcomes. On the other hand, it makes an important contribution to the developmentof the literature, since it is one of the few studies that evaluated the prevalence and associated factors, not only the exclusive use of pacifiers and feeding bottle, but also the combined use of these artificial nipples.

This research has verified a high prevalence of pacifier use and/ or feeding bottle in children younger than one year old in the city of Vitória da
Conquista, Bahia. The use of these artificial nipples was associated with maternal sociodemographic factors, such as age, marital status, schooling, working outside the home, besides the experience and difficulties in the breastfeeding process and the encouragement of breastfeeding in puericulture.

These findings demonstrate the importance of knowing the social determinants in which this population is inserted, which may help the creation and implementation of health policies with the objective of reducing the use of pacifier and feeding bottle as well as the negative consequences associated with using these artificial nipples.

\section{Acknowledgments}

The Health Municipal Secretary of Vitória da Conquista - Bahia and the nursing team of the Health Units for the logistical support in data collection.

\section{Author's contribution}

Bezerra VM contributed with the revision of literature, data analysis and revision and writing of the manuscript. Magalhães EIS contributed with data collection and revision of the manuscript. Gomes AT and Pereira IN contributed with data analysis and writing of the manuscript. Pereira Netto $M$ contributed with the conception of the project and revision of the manuscript. Rocha DS contributed with the conception of the project, data collection coordination and revision of the manuscript. All authors approved the final version of the manuscript.

\section{References}

1. Protecting, promoting and supporting breastfeeding: the special role of maternity services. A joint WHO/UNICEF statement. Genebra, Suíça: World Health Organization; 1989.

2. Zimmerman E, Thompson K. Clarifying nipple confusion. J Perinatol. 2015; 35 (11): 895-9.

3. Rigotti RR, Oliveira MICD, Boccolini CS. Association between the use of a baby's bottle and pacifier and the absence of breastfeeding in the second six months of life. Ciênc Saúde Coletiva. 2015; 20 (4): 1235-44.

4. Sociedade Brasileira de Pediatria. Departamento Científico de Aleitamento Materno. Guia prático de atualização. Uso de chupeta em crianças amamentadas: prós e contras; 2017.

5. Avila WM, Pordeus IA, Paiva SM, Martins CC. Breast and bottle feeding as risk factors for dental caries: a systematic review and meta-analysis. PLoS One. 2015; 10 (11): e0142922.

6. Costa CT, Shqair AQ, Azevedo MS, Goettems ML, Bonow MLM, Romano AR. Pacifier use modifies the association between breastfeeding and malocclusion: a cross-sectional study. Braz Oral Res. 2018; 32: e101-7.

7. Moraes MS, Araújo BC, Costa LEO, Nascimento JS. Shigella in baby bottles of a Brazilian newborn nursery. J Infect Dev Ctries. 2015; 9 (6): 679-81.

8. Brasil. Lei no 11.265 de 03 de janeiro de 2006. Regulamenta a comercialização de alimentos para lactentes e crianças de primeira infância e também a de produtos de puericultura correlatos. [acesso em 11 de abril de 2018] Disponível em: <http://www.planalto.gov.br/ccivil_03/ _Ato2004-2006/2006/Lei/L11265.htm>

9. Tomasi E, Victora CG, Olinto MTA. Padrões e determinantes do uso de chupeta em crianças. J Pediatr. 1994; 70 (3): $167-71$ 
10. Pinto MCGL, Melo GFB, Colares V, Katz CRT. Fatores sócio-econômico-culturais relacionados ao uso da chupeta em crianças de zero a quatro anos da cidade do Recife-PE. Arq Odontol. 2003; 39 (4): 285-96.

11. França MCT, Giugliani ERJ, Oliveira LDD, Weigert EML, Santo LCDE, Köhler CV, Bonilha AL. Uso de mamadeira no primeiro mês de vida: determinantes e influência na técnica de amamentação. Rev Saúde Pública. 2008; 42 (4): 607-14.

12. Shamim S, Jamalvi SW, Naz F. Determinants of bottle use amongst economically disadvantaged mothers. J Ayub Med Coll Abbottabad. 2006; 18 (1): 48-51.

13. Buccini GS, Benício MHD, Venancio SI. Determinantes do uso de chupeta e mamadeira. Rev Saúde Pública. 2014; 48 (4): 571-82.

14. Brasil. Ministério da Saúde. Secretaria de Atenção à Saúde. Departamento de Ações Programáticas e Estratégicas. II Pesquisa de Prevalência de Aleitamento Materno nas Capitais Brasileiras e Distrito Federal / Ministério da Saúde, Secretaria de Atenção à Saúde, Departamento de Ações Programáticas e Estratégicas. - Brasília, DF; 2009. $108 \mathrm{p}$

15. Victora CG, Huttly SR, Fuchs SC, Olinto MT. The role of conceptual frameworks in epidemiological analysis: a hierarchical approach. Int J Epidemiol. 1997; 26 (1): 224-7.

16. Santos TR, Buccini, GS, Sebastião, LT. Fatores associados ao uso de chupeta entre filhos de mulheres trabalhadoras com creche no local de trabalho. Rev CEFAC. 2017; 19 (5): 654-63.

17. Cruz SHD, Germano JDA, Tomasi E, Facchini LA, Piccini RX, Thumé E. Orientações sobre amamentação: a vantagem do Programa de Saúde da Família em municípios gaúchos com mais de 100.000 habitantes no âmbito do PROESF. Rev Bras Epidemiol. 2010; 13 (2): 259-67.

18. Kramer MS, Barr RG, Degenais S, Yang H, Jones P, Ciofani L, Jané F. Pacifier use, early weaning, and cry/fuss behavior: a randomized controlled trial. JAMA. 2001; 286 (3): 322-6.

19. Victora CG, Behague DP, Barros FC, Olinto MTA, Weiderpass E. Pacifier use and short breastfeeding duration: cause, consequence, or coincidence? Pediatrics. 1997; 99 (3): 445-53.

Received on August 1, 2018

Final version presented on February 12, 2019

Approved on March 26, 2019
20. Batista CL, Ribeiro VS, Nascimento MD, Rodrigues VP. Association between pacifier use and bottle-feeding and unfavorable behaviors during breastfeeding. J Pediatr. 2018; 94 (6): 596-601.

21. Jaafar SH, Jahanfar S, Angolkar M, Ho JJ. Effect of restricted pacifier use in breastfeeding term infants for increasing duration of breastfeeding. Cochrane Database Syst Rev 2012; 7: CD007202.

22. Soares MEM, Giugliani ERJ, Braun ML, Salgado ACN, Oliveira AP, Aguiar PR. Uso de chupeta e sua relação com o desmame precoce em população de crianças nascidas em Hospital Amigo da Criança. J Pediatr. 2003; 79 (4): 309-16.

23. Spinelli MGN, Souza SBD, Souza JMP. Mamadeira, xícara ou colher: de que forma os bebês estão recebendo os alimentos. Pediatr Mod. 2002; 38 (10): 461-8.

24. Gomes CF, Trezza EMC, Murade ECM, Padovani CR. Surface electromyography of facial muscles during natural and artificial feeding of infants. J Pediatr. 2006; 82 (2):103-9.

25. Sertório SCM, Silva IA. As faces simbólica e utilitária da chupeta na visão de mães. Rev Saúde Pública. 2005; 39 (2): 156-62.

26. Brasil. Ministério da Saúde. Secretaria de Atenção à Saúde. Departamento de Atenção Básica. Saúde da criança: aleitamento materno e alimentação complementar. 2 ed. Brasília, DF; 2015. $184 \mathrm{p}$

27. Faleiros FTV, Trezza EMC, Carandina L. Aleitamento materno: fatores de influência na sua decisão e duração. Rev Nutr. 2006; 19 (5): 623-30.

28. Silva PP, Silveira RB, Mascarenhas MLW, Silva MB, Kaufmann CC, Albernaz EP. A percepção das mães sobre o apoio paterno: influência na duração do aleitamento materno. Rev Paul Pediatr. 2012; 30 (3): 306-13.

29. Rea MF, Venancio SI, Batista LE, Santos RG, Greiner T. Possibilidades e limitações da amamentação entre mulheres trabalhadoras formais. Rev Saúde Pública. 1997; 31 (2): 149-56. 